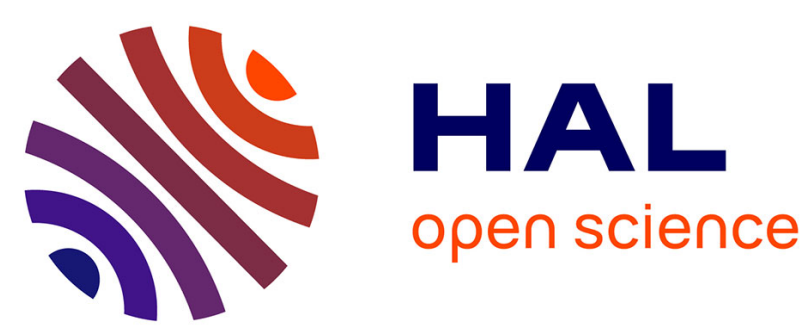

\title{
INFLUENCE DE LA COMPOSITION DU COMPLÉMENTAIRE PROTIDIQUE SUR LE COMPORTEMENT ALIMENTAIRE ET LES PERFORMANCES DU PORC EN CROISSANCE
}

J. Lougnon

\section{To cite this version:}

J. Lougnon. INFLUENCE DE LA COMPOSITION DU COMPLÉMENTAIRE PROTIDIQUE SUR LE COMPORTEMENT ALIMENTAIRE ET LES PERFORMANCES DU PORC EN CROISSANCE. Annales de zootechnie, 1973, 22 (3), pp.371-372. hal-00887287

\section{HAL Id: hal-00887287 https://hal.science/hal-00887287}

Submitted on 1 Jan 1973

HAL is a multi-disciplinary open access archive for the deposit and dissemination of scientific research documents, whether they are published or not. The documents may come from teaching and research institutions in France or abroad, or from public or private research centers.
L'archive ouverte pluridisciplinaire HAL, est destinée au dépôt et à la diffusion de documents scientifiques de niveau recherche, publiés ou non, émanant des établissements d'enseignement et de recherche français ou étrangers, des laboratoires publics ou privés. 
Comparée à un régime normal (I3 repas de même composition apportant, par semaine, les mêmes quantités d'énergie et de protéines) cette dissociaton provoque chez les femelles, et contrairement aux mâles castrés, une diminution des bilans azotés $(19,2$ contre $22,7 \mathrm{~g} / \mathrm{j}$ ), un ralentissement de la croissance $(6 \mathrm{r} 8$ contre $694 \mathrm{~g} / \mathrm{j}$ entre 26 et roo $\mathrm{kg}$ ) et une augmentation des indices de consommation (3,06 contre $2,79 \mathrm{~kg} \mathrm{MS} / \mathrm{kg}$ gain).

La légère amélioration des carcasses que l'on constate pourrait être attribuable à la moindre lipogenèse consécutive aux repas $\mathrm{HN}$; elle ne compense pas les inconvénients cités.

\title{
SUMMARY
}

\section{EFFECT OF GIVING PROTEIN SUPPLEMENT TWICE A WEEK \\ TO A LOW NITROGEN DIET ON CARCASS COMPOSITION IN GROWING FEMALES}

The influence of dissociating energy and protein feeding during one week (I I feeds at a low nitrogen level (LN) and 2 feeds at a high level of nitrogen (HN) providing a total amount of $4^{\circ}$ percent protein) was studied with female pigs and compared with the results previously obtained with castrated male pigs.

The control pigs were fed a constant amount of protein at each meal. Control and experimental animals received the same amounts of protein and energy per week.

In opposition to castrated pigs and compared to controls, the female pigs subjected to dissociated feeding had the lowest $\mathrm{N}$ balance (19,2 versus $22,7 \mathrm{~g} /$ day), the slowest growth rate (618 versus $694 \mathrm{~g} /$ day between 26 and $100 \mathrm{~kg})$ and the highest feed conversion $(3,06$ versus $2,79 \mathrm{~kg}$ dry matter/kg live-weight gain). The best quality of carcasses we observed could be explained by the low lipogenesis after HN meals. It did not compensate the mentioned disadvantages.

\section{INFLUENCE DE LA COMPOSITION DU COMPLÉMENTAIRE PROTIDIQUE SUR LE COMPORTEMENT ALIMENTAIRE ET LES PERFORMANCES DU PORC EN CROISSANCE}

\author{
J. LOUGNON \\ A. E. C. - Société de Chimie organique et biologique \\ 03600 Commentry

\section{RÉSUMÉ}

Deux expériences sont réalisées en vue de préciser le comportement alimentaire du porc en croissance disposant en permanence et à volonté d'un régime à base de céréales (blé-maïs) et d'un régime complémentaire de composition variable.

Dans la première expérience, on utilise 4 régimes complémentaires dont les taux de protéines brutes et de lysine (p. Ioo) sont les suivants : $24-1,2$ (I); $50-1,2$ (2) ; $24-3,3$ (3) ; $50-3,3(4)$. Les animaux refusent le régime $(2)$ et ont par suite des performances très 
médiocres. Entre 20 et $90 \mathrm{~kg}$, les porcs se constituent une ration dont les teneurs en protéines brutes et lysine (p. Ioo) sont les suivantes :

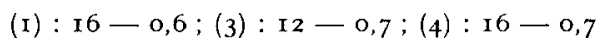

En ajoutant au régime (2) des acides aminés libres de manière à atteindre des taux analogues à ceux du régime (4), on observe des consommations et des performances semblables à celles obtenues avec ce régime (4) (2e expérience).

\section{SUMMARY}

\section{EFFECT OF PROTEIN SUPPLEMENT COMPOSITION ON FEED CONSUMPTION AND PERFORMANCES OF GROWING PIGS}

Two experiments were carried out to determine the feed intake of growing pigs constantly fed an ad libitum diet based on cereals (wheat, maize) and a supplementary diet of varying composition.

In the first experiment, 4 supplementary diets were used. Their levels of crude protein and lysine (p. Ioo) were as follows : $24-\mathrm{I}, 2$ (I) ; $50-\mathrm{I}, 2(2) ; 24-3,3$ (3); $50-3,3$ (4). The animals refused the diet (2) and then showed poor performances. Between 20 and $90 \mathrm{~kg}$, pigs consumed a diet whose crude protein and lysine levels (p. Ioo) were as follows :

$$
\text { (1) : I6-0,6;(3): 1 } 2-0,7 ;(4): 16-0,7
$$

By supplementing diet (2) with free amino acids so as to reach levels similar to those of diet 4 , it could be noticed that feed intakes and performances were similar to those obtained with diet 4 (second experiment). 